\title{
Estimasi Nilai Pergeseran Gempa Bumi Padang Tahun 2009 Menggunakan Data GPS SuGAr
}

\author{
I Dewa Made Amertha Sanjiwani ${ }^{1)}$, Ira Mutiara Anjasmara ${ }^{2)}$, Meiriska Yusfania ${ }^{3)}$ \\ Jurusan Teknik Geomatika, Fakultas Sipil dan Perencanaan, Institut Teknologi Sepuluh Nopember \\ (ITS) \\ Jl. Arief Rahman Hakim, Surabaya 60111 Indonesia \\ email: $\underline{\text { ira@geodesy.its.ac.id; } y u s f a n i a \_m e i @ g e o d e s y . i t s . a c . i d ~}$
}

\begin{abstract}
Abstrak - Indonesia terletak pada pertemuan tiga lempeng tektonik yaitu Lempeng Eurasia, Lempeng Indo - Australia dan Lempeng Pasifik. Akibatnya gempa bumi dan letusan gunung api sering terjadi pada batas-batas lempeng tersebut. Pada 30 September 2009, di sekitar wilayah Padang, Pariaman terjadi gempa berkekuatan 7.6 Mw dengan lokasi epicenter 99'52'1.2” BT; 0 43'12" LS. Melalui pemantauan GPS dapat diketahui pergerakan deformasi yang terjadi sebelum (interseismic) dan setelah (postseismic) akibat gempa (coseismic). Untuk itu dalam penelitian ini dilakukan estimasi nilai pergeseran akibat Gempa Bumi Padang tahun 2009 menggunakan data GPS SuGAr. Hasil analisa didapatkan nilai pergeseran terbesar terjadi pada stasiun pengamatan GPS PPNJ dengan nilai pergeseran sebesar 0.01222 m pada sumbu horizontal (easting,northing) dan $0.001 \mathrm{~m}$ pada sumbu vertikal (up). Nilai pergeseran terkecil dimiliki oleh stasiun pengamatan KTET dengan nilai pergeseran sebesar $0.00185 \mathrm{~m}$ pada sumbu horizontal (easting,northing) dan $0.01114 \mathrm{~m}$ pada sumbu vertikal (up).
\end{abstract}

Kata Kunci-Gempa Padang 2009, SuGAr, Deformasi, Nilai Pergeseran

\section{PENDAHULUAN}

G EMPA bumi adalah getaran atau guncangan yang terjadi dipermukaan bumi akibat pelepasan energi dlam scara tiba-tiba yang menciptakan gelombang seismik. Gempa bumi disebabkan oleh pergerakan kerak bumi (lempeng bumi). Gempa bumi di bagi menjadi tiga yaitu: gempa bumi tektonik, gemba bumi vulkanik dan gempa bumi runtuhan. Penyebab terjadinya gempa bumi tektonik adalah adanya pergeseran lempeng-lempeng tektonik secara mendadak yang mempunyai kekuatan yang sangat besar (pelepasan energi yang terjadi akibat pergeseran lempeng tektonik) [1].

Indonesia terletak pada pertemuan tiga lempeng tektonik, yaitu lempeng Eurasia, lempeng Hindia - Australia, dan lempeng Pasifik. Pada daerah sekitar batas lempeng tersebut umumnya aktifitas tektonik utama berlangsung, seperti misalnya subduksi, tumbukan (collision), pemekaran punggung tengah samudera dan sesar transform [2]. Akibatnya gempa bumi dan letusan gunung api akan sering terjadi tidak jauh dari batas-batas lempeng tersebut.

Pulau Sumatera termasuk salah satu pulau terbesar di ]Indonesia. Pulau ini merupakan salah satu wilayah dengan aktifitas tektonik terbesar di dunia. Pulau Sumatera mengakomodasi tumbukan lempeng Indo - Australia yang mensubduksi lempeng Eurasia dengan kecepatan 5-6 cm/tahun [3] . Hal ini mengakibatkan pulau Sumatera rawan terjadi gempa tektonik yang disebabkan dari pergerakan lempeng tersebut. Salah satu gempa terbesar yang terjadi di pulau ini adalah gempa Kota Padang, Pariaman pada tahun 2009 dengan magnitude gempa 7.6 Skala Richter (SR) pada lokasi koordinat epicenter 99 52'1.2" BT; 043'12" LS dan kedalaman $81 \mathrm{~km}$.

Kota Padang, Pariaman merupakan kota yang terletak memanjang dibagian barat pulau Sumatera dan dikelilingi oleh Samudera Hindia. Kota Padang, Pariaman merupakan bagian serangkaian pulau non-vulkanik dan kota tersebut merupakan puncak-puncak dari suatu punggung pengunungan bawah laut.

Meskipun gempa bumi ini dirasakan hingga seluruh pulau Sumatera, Malaysia dan Singapura, baiknya adalah kerugian yang diakibatkan oleh gempa ini tidak terlalu besar dibandingkan dengan gempa bumi yang terjadi di pulau Sumatera sebelumnya. Namun prinsipnya, gempa bumi biasanya akan menyebabkan kerak bumi disekitarnya terdeformasi dengan baik dalam arah vertikal dan horizontal. Oleh sebab itu, kemungkinan besar gempa Padang tahun 2009 juga menyebabkan aktivitas deformasi kerak bumi.

Menghitung estimasi nilai pergeseran yang terjadi di kota Padang, Pariaman dan sekitarnya diperlukan data GPS SuGAr. Nilai pergeseran akibat gempa bumi yang didapat merupakan deformasi yang terjadi di Padang dan sekitarnya.

Dengan adanya pengamatan GPS dengan menggunakan data SuGAr, studi deformasi akibat gempa Padang tahun 2009 dapat dilakukan guna pembuatan model bencana gempa bumi berikutnya sebagai salah satu bentuk dalam mitigasi bencana bagi masyarakat Padang dan sekitarnya

\section{MEtodologi PENELITIAN}

\section{A. Lokasi Penelitian}

Lokasi penelitian ini adalah gempa bumi yang terjadi di Padang, Pariaman, Sumatera Barat pada tanggal 30 September 2009 dengan gempa sebesar 7.6 skala richter (SR) dengan kedalaman $81 \mathrm{~km}$. Posisi episenter geografis terletak pada koordinat $99^{\circ} 52^{\prime} 1.2^{\prime \prime}$ BT; 043'12” LS yang berada pada jalur lempeng tektonik. 


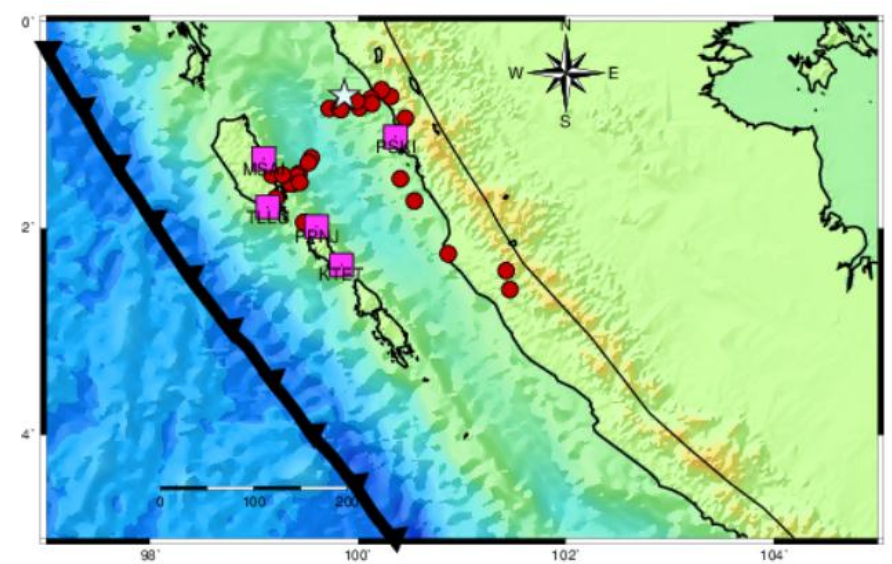

Gambar 1 Lokasi Penelitian

\section{B. Data dan Peralatan}

Data yang digunakan adalah data pengamatan GPS berupa data RINEX pada bulan September 2009 hingga Oktober 2009, yakni day of year ke-244 hingga 304. Data tersimpan dalam format RINEX dengan sampling pengukuran tiap lima belas detik. Data GPS bersumber dari hasil pemantauan online. Data pengamatan diunduh di salah satu penyedia data Sumateran GPS Array (SuGAr) yaitu "Scripps Orbit and Permanent Array" (SOPAC). Data stasiun pengamatan yang digunakan adalah data stasiun MSAI, KTET, PPNJ, PSKI dan TLLU. Data lain yang dibutuhkan adalah data gempa bumi Padang tahun 2009 yang diunduh pada website USGS

Peralatan yang digunakan antara lain adalah hardware berupa stasiun GPS Online serta software berupa sistem operasi LINUX Ubuntu 14.04 dan Windows 10, Microsoft Word dan Excel, Software Generic Mapping Tools (GMT) dan software GAMIT/GLOBK

\section{Diagram Alir Pengolahan Data}

Pengolahan data dapat dijelaskan dengan diagram alir pada Gambar 2 sebagai berikut.

Tahapan pengolahan data berdasarkan gambar 2 adalah sebagai berikut:

1) Persiapan data dan pendukung lainnya adalah tahap dimana proses download data RINEX dari pusat data di SOPAC. Dibutuhkan beberapa pendukung lainnya sebelum memulai proses pengolahan data seperti data receiver dan informasi antenna untuk setiap data (file station.info), list station, titik ikat kontrol file, IGS SP3 ephemeris file, nilai jam satelit, file navigasi RINEX. Data Gempa Bumi juga diperlukan untuk proses pengoalahan selanjutnya.

2) Proses pengolahan data dengan GAMIT, pengolahan data GPS dengan menggunakan GAMIT adalah membuat direktori pekerjaan EXPT dan menghubungkan seluruh file yang dibutuhkan seperti control file yang terletak di "gg/tables/dengan perintah sh_gamit.

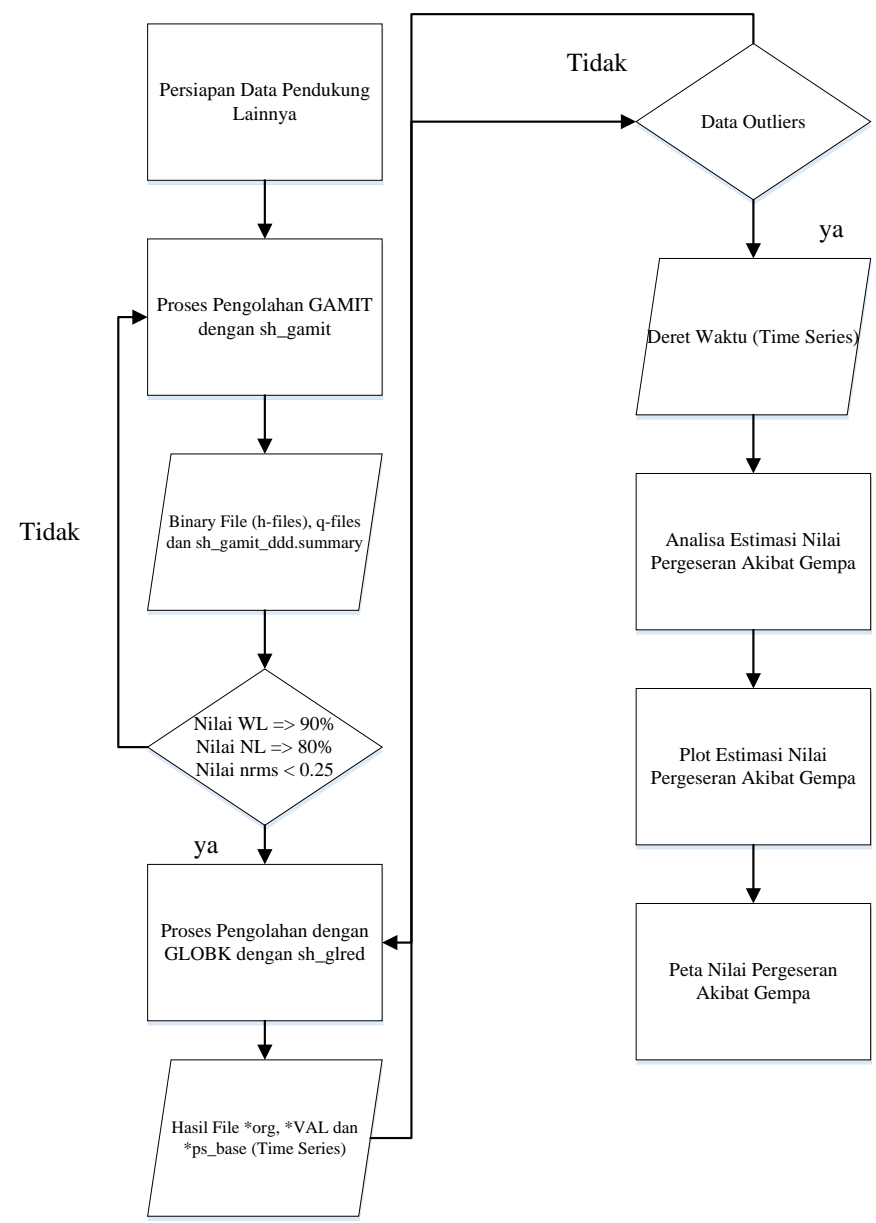

Gambar 2 Diagram Alir Pengolahan Data

3) Evaluasi solusi GAMIT, pada proses ini dapat dikatakan baik atau salah dengan melihat $h$-file. $Q$-file dan postfit.autcl.summary. parameter yang dicek adalah:

a) Nilai postfit nrms (normalized root mean square). Nilai postfit solusi harian harus kurang dari 0.25 . Apabila nilai postfit nrms lebih besar dari 0.5 maka data GPS masih terdapat efek cycle slip [4]

b) Nilai ambiguitas fase Wide Lane, apabila nilai atau hasil pengolahan harian GAMIT harus berada di atas $90 \%$ dan $80 \%$ untuk masing-masing nilai. Demikian juga halnya dengan Narrow Lane.

4) Proses pengolahan dengan GLOBK, pada tahapan ini kombinasi DOY dan plotting parameter koordinat $h$-file secara time series. Hasil yang didapat dari GLOBK adalah time series. Apabila terdapat data outlier maka terlebih dahulu harus dihilangkan data outlier-nya dengan menggunakan aplikasi yang tersedia oleh GLOBK

5) Hasil akhir adalah time series yang sudah hilang outliersnya dan dapat dilakukan pencarian nilai pergeseran.

6) Analisa nilai pergeseran yang telah dihasilkan oleh software GAMIT/GLOBK. Hasilnya berupa nilai pergeseran per stasiun pengamatan GPS

7) Setelah dilakukan analisa, plotting nilai pergeseran berdasarkan hasil analisa yang telah dilakukan

8) Hasil akhir berupa peta nilai pergeseran akibat gempa. 


\section{HASIL DAN ANALISA}

\section{A. Hasil Pengolahan GAMIT}

Hasil pengolahan GAMIT berupa nilai harian ambiguitas fase Wide Lane dan Narrow Lane serta nilai postfit nrms yang dijelaskan pada Gambar 3, Gambar 4 dan Gambar 5.

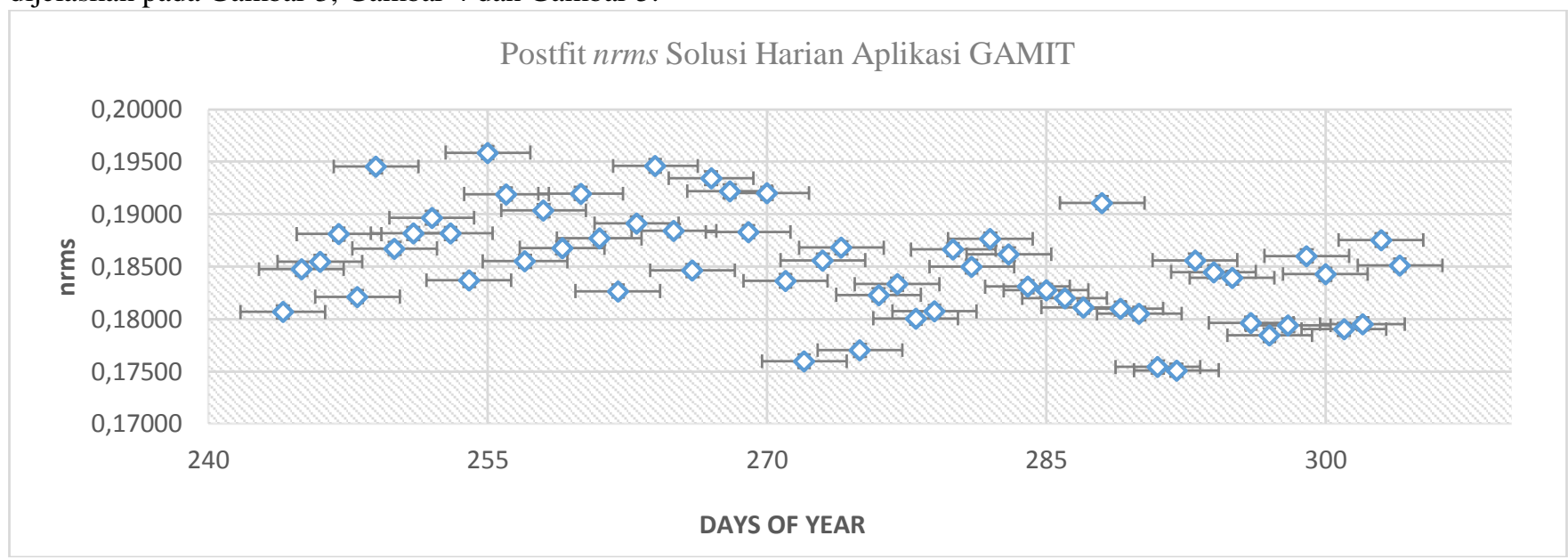

Gambar 3 Nilai nrms Harian Solusi GAMIT

Gambar 3. Menunjukkan bahwa nilai nrms minimal adalah sebesar 0.17512 dan nilai nrms maksimal adalah sebesar 0.19588 serta nilai rerata $\mathrm{nrms}$ adalah sebesar 0.18515 . Hal ini menunjukkan bahwa metode penggunaan GAMIT sesuai dengan kriteria

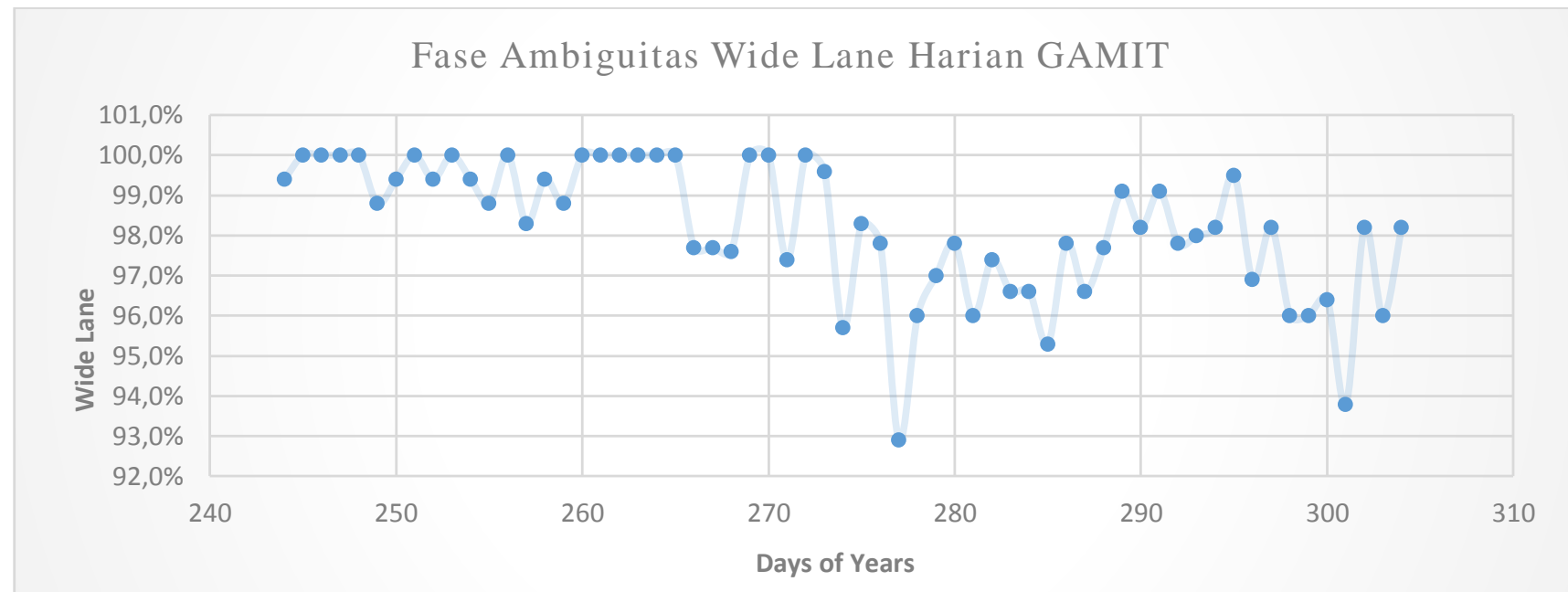

Gambar 4 Fase Ambiguitas Wide Lane Harian GAMIT

Gambar 4 menunjukkan bahwa nilai maksimal Wide Lane pada penelitian ini sebesar $100 \%$ dan nilai reratanya sebesar $98.21 \%$ serta nilai minimumnya sebesar $92.90 \%$. hal ini menunjukkan bahwa hasil pengolahan data GPS masuk toleransi yang telah diberikan oleh software GAMIT. 


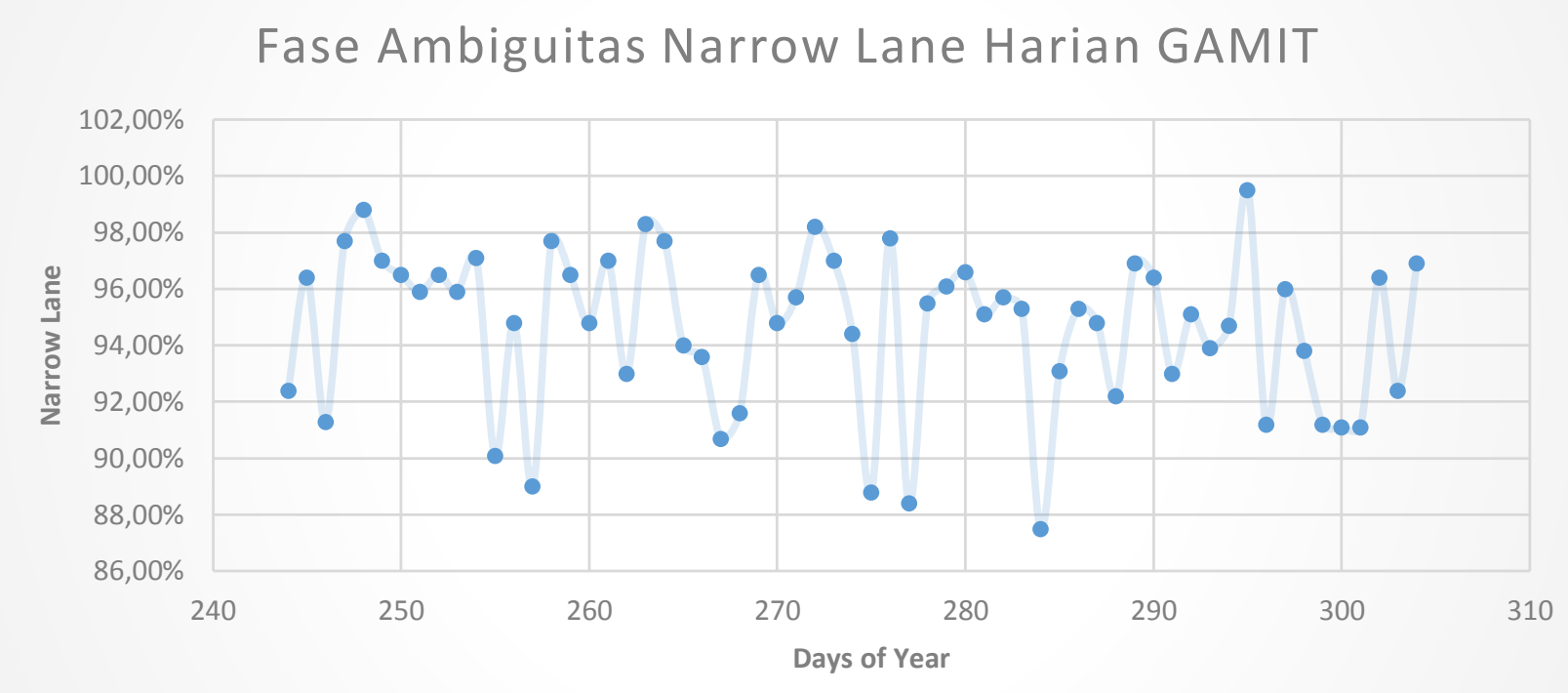

Gambar 5 Resolusi Ambiguitas Fase Narrow Lane Sepanjang Observasi

\section{B. Hasil pengolahan GLOBK}

Hasil pengolahan GLOBK berupa time series seluruh waktu data GPS yang dikombinasikan. Tujuan dari time series ini adalah untuk menentukan fungsi matematika dari data yang dihasilkan oleh software pengolah GPS sepanjang waktu pengamatan (DoY) dan menghapus outlier [5]. Gambar 6 menunjukkan salah satu stasiun pengamatan GPS yaitu stasiun MSAI.
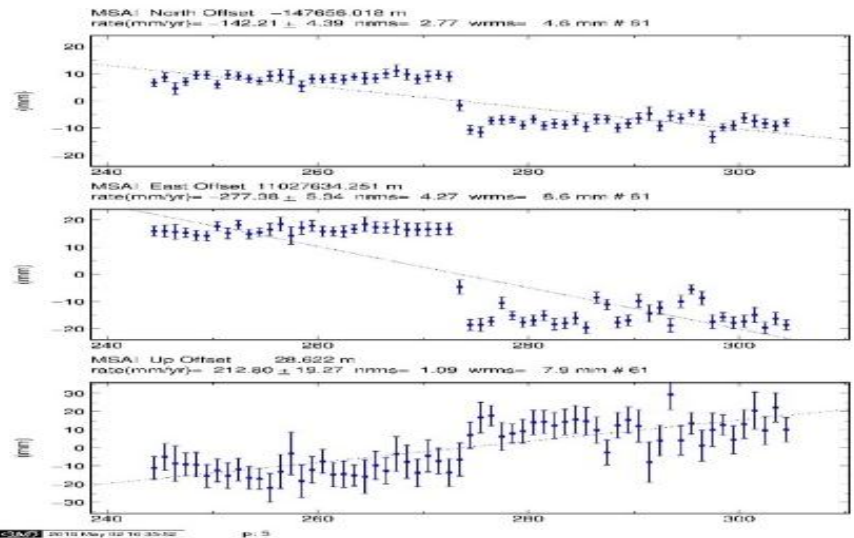

Gambar 6 Time Series Stasiun MSAI DoY 244 - 304

Gambar 6 menunjukkan time series stasiun GPS MSAI di atas memiliki nilai rms sebesar 4.6 $\mathrm{mm}, 8.6 \mathrm{~mm}$ dan $7.9 \mathrm{~mm}$ untuk sumbu masingmasing northing, easting dan up. Hal tersebut sudah masuk dalam toleransi rms yaitu sebesar 10 $\mathrm{mm}$.

C. $\quad$ Uji Kualitas Data GPS Interseismic Sebelum Removing Outlier dan Sesudah Removing Outlier

Analisa kualitas data GPS dilakukan secara terpisah antara dua fase gempa agar pemodelan dan penenentuan nilai root-mean-square (RMS) error tidak terpengaruh akibat bias gempa, yakni interseisimic dan postseismic [6]. Tabel 1 menunjukkan bahwa nilai rms tiap masing-masing stasiun sebelum dihilangkan outliers-nya pada fase interseismic

Tabel 1.

RMS data GPS Interseismic Sebelum Removing Outliers

\begin{tabular}{cccc}
\hline $\begin{array}{c}\text { Stasiun } \\
\text { GPS }\end{array}$ & $\begin{array}{c}\text { RMS } \\
\text { Northing } \\
( \pm \mathrm{mm})\end{array}$ & $\begin{array}{c}\text { RMS } \\
\text { Easting } \\
( \pm \mathrm{mm})\end{array}$ & $\begin{array}{c}\text { RMS } \\
\mathrm{Up}( \pm \mathrm{mm})\end{array}$ \\
\hline PSKI & 1.3 & 2.6 & 7.4 \\
PPNJ & 1.6 & 1.2 & 5.9 \\
MSAI & 1.3 & 1.2 & 4.5 \\
TLLU & 2.3 & 1.2 & 5.5 \\
KTET & 1.4 & 1.9 & 5.3 \\
\hline \hline
\end{tabular}


Tabel 2 menunjukkan bahwa nilai rms tiap masing-masing stasiun sesudah dihilangkan outliers-nya pada fase interseismic.

Tabel 2.

Nilai RMS Stasiun GPS setelah Removing Outlier

\begin{tabular}{cccc}
\hline \hline $\begin{array}{c}\text { Stasiun } \\
\text { GPS }\end{array}$ & $\begin{array}{c}\text { RMS } \\
\text { Northing } \\
( \pm \mathrm{mm})\end{array}$ & $\begin{array}{c}\text { RMS } \\
\text { Easting } \\
( \pm \mathrm{mm})\end{array}$ & $\begin{array}{c}\text { RMS } \\
\mathrm{Up}( \pm \mathrm{mm})\end{array}$ \\
\hline PSKI & 1.0 & 1.7 & 3.7 \\
PPNJ & 1.0 & 1.6 & 5.9 \\
MSAI & 1.0 & 1.4 & 4.0 \\
TLLU & 1.6 & 1.2 & 5.9 \\
KTET & 1.0 & 1.3 & 4 \\
\hline \hline
\end{tabular}

D. Uji Kualitas Data GPS Postseismic Sebelum Removing Outlier dan Sesudah Removing Outlier

Untuk analisa data GPS pasca gempa, dilakukan pengamatan mulai dari DoY 274-304 kemudian didapatkan RMS error dari data mentah untuk masingmasing stasiun GPS sebelum dihilangkan outliernya yang dijelaskan pada Tabel 3.

Tabel 3.

RMS Error Data GPS Postseismic Sebelum Removing Outlier

\begin{tabular}{cccc}
\hline \hline $\begin{array}{c}\text { Stasiun } \\
\text { GPS }\end{array}$ & $\begin{array}{c}\text { RMS } \\
\text { Northing } \\
( \pm \mathrm{mm})\end{array}$ & $\begin{array}{c}\text { RMS } \\
\text { Easting } \\
( \pm \mathrm{mm})\end{array}$ & $\begin{array}{c}\text { RMS } \\
\mathrm{Up}( \pm \mathrm{mm})\end{array}$ \\
\hline PSKI & 1.7 & 2.9 & 8.8 \\
PPNJ & 1.6 & 3.0 & 6.3 \\
MSAI & 1.9 & 1.2 & 4.5 \\
TLLU & 1.7 & 4.0 & 6.5 \\
KTET & 2.0 & 3.5 & 6.3 \\
\hline \hline
\end{tabular}

Tabel 4 menunjukkan RMS error data GPS setelah dihilangkan outlier-nya dengan menggunakan uji stastistik kualitatif sebesar $95 \%$ atau 2 kali RMS error.

Tabel 4.

RMS Error Data GPS Postseismic Setelah Removing Outlier

\begin{tabular}{cccc}
\hline \hline Stasiun GPS & $\begin{array}{c}\text { RMS } \\
\text { Northing } \\
( \pm \mathrm{mm})\end{array}$ & $\begin{array}{c}\text { RMS } \\
\text { Easting } \\
( \pm \mathrm{mm})\end{array}$ & $\begin{array}{c}\text { RMS } \\
\mathrm{Up}( \pm \mathrm{mm})\end{array}$ \\
\hline PSKI & 2.1 & 2.9 & 6.6 \\
PPNJ & 2.2 & 2.6 & 6.7 \\
MSAI & 1.7 & 1.9 & 5.2 \\
TLLU & 2.1 & 2.4 & 4.7 \\
KTET & 3.1 & 2.7 & 3.7 \\
\hline \hline
\end{tabular}

Melihat nilai RMS hasil filtering seperti yang ditunjukkan pada Tabel 4, maka sudah dapat melanjutkan ke tahap penentuan arah dan besar pergeseran karena hasil RMS di bawah dari nilai 10 $\mathrm{mm}$.

\section{E. Analisa Nilai Pergeseran Horisontal Stasiun} GPS akibat Gempa Padang 2009

Dengan melakukan pengolahan data GPS yang telah dihilangkan outlier-nya, maka dapat dilakukan penentuan besar pergeseran secara horisontal yang ditunjukkan pada Tabel 5.

Nilai yang didapat pada Tabel 5 diambil pada rumus (1) sebagai berikut [7]:

$$
\begin{array}{r}
\mathrm{X}_{\mathrm{t}}=\left(\mathrm{t}-\mathrm{t}_{0}\right)+\mathrm{X}_{\mathrm{t} 0} . \\
\text { Tabel } 5 .
\end{array}
$$

Pergeseran Horizontal (coseismic)

\begin{tabular}{cccc}
\hline \hline Titik Pengamatan & $\mathrm{dE}(\mathrm{m})$ & $\mathrm{dN}(\mathrm{m})$ & $\begin{array}{c}\text { Resultan } \\
(\mathrm{m})\end{array}$ \\
\hline PSKI & -0.00470 & -0.00580 & 0.00746 \\
PPNJ & -0.01124 & -0.00481 & 0.01222 \\
MSAI & -0.00531 & -0.00708 & 0.00885 \\
TLLU & -0.00317 & -0.00098 & 0.00331 \\
KTET & 0.00101 & 0.00156 & 0.00185 \\
\hline \hline
\end{tabular}

dimana $X_{t}$ merupakan koordinat pengamatan di epok t, kemudian $X_{t 0}$ adalah koordinat stasiun pengamatan di epok $t_{0}, t_{0}$ adalah waktu pengamatan koordinat stasiun pertama, $t$ adalah waktu pengamatan koordinat stasiun terakhir, dan $V$ adalah besar pergeserannya. Nilai pergeseran $V$ dapat dihitung dengan menggunakan rumus (2) sebagai berikut:

$$
R=\sqrt{(d N)^{2}+(d E)^{2}}
$$

Dimana $\mathrm{dE}$ dan $\mathrm{dN}$ merupakan nilai parameter pergeseran pada sumbu easting dan northing. Dengan menggunakan kedua rumus tersebut di dapatkan nilai pergeseran horizontal yang ditunjukkan pada Tabel 5 akibat gempa (coseismic) beserta visualisasinya pada Gambar 7.

Arah pergeseran akibat gempa Padang tahun 2009 digunakan rumus (3) berikut:

$$
\alpha=\operatorname{atan} \frac{\mathrm{dE}}{d N}
$$

Rumus (3) digunakan untuk menghasilkan arah pergeseran coseismic dan menghasilkan arah pergeseran yang ditampilkan pada Tabel 6 .

Tabel 6.

Arah Pergeseran Horisontal Coseismic

\begin{tabular}{ccc}
\hline \hline Titik Pengamatan & Arah Sudut & Kuadran \\
\hline PSKI & S $50^{\circ} 57^{\prime} 54.63^{\prime \prime} \mathrm{W}$ & Kuadran III \\
PPNJ & S $23^{\circ} 09^{\prime} 19.83^{\prime \prime} \mathrm{E}$ & Kuadran II \\
MSAI & S $53^{\circ} 08^{\prime} 01.66^{\prime \prime} \mathrm{W}$ & Kuadran III \\
TLLU & N $17^{\circ} 08^{\prime} 20.49^{\prime \prime} \mathrm{W}$ & Kuadran II \\
KTET & N $57^{\circ} 05^{\prime} 33.25^{\prime \prime} \mathrm{E}$ & Kuadran I \\
\hline
\end{tabular}

\section{F. $\quad$ Analisa Vektor Pergeseran Vertikal Akibat}

Gempa Padang 2009

Dengan melakukan pengolahan data GPS yang telah dihilangkan outlier-nya, maka dapat dilakukan penentuan besar pergeseran secara horisontal yang ditunjukkan pada Tabel 7.

Tabel 7 menunjukkan nilai pergeseran yang terjadi secara vertikal akibat Gempa Padang 2009 (coseismic). 


\section{G. Hasil Nilai Pergeseran Horisontal dan} Vertikal

Adapun hasil nilai pergeseran yang dihasilkan ditunjukkan pada Gambar 7. untuk nilai pergeseran horizontal dan Gambar 8 untuk nilai pergeseran horizontal.

Tabel 7.

Nilai Pergeseran Vertikal Coseismic

\begin{tabular}{cc}
\hline \hline Titik Pengamatan & Pergeseran Vertikal $(\mathrm{m})$ \\
\hline PSKI & 0.00277 \\
PPNJ & 0.02083 \\
MSAI & 0.01579 \\
TLLU & 0.01904 \\
KTET & 0.01195 \\
\hline \hline
\end{tabular}

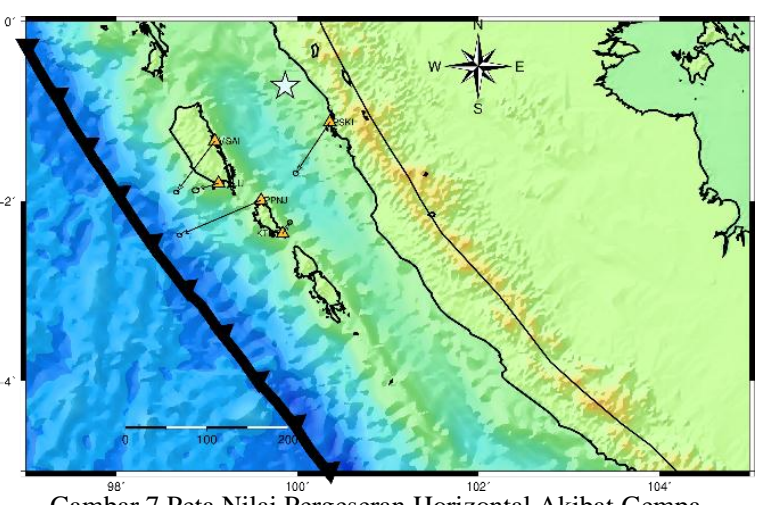

Gambar 7 Peta Nilai Pergeseran Horizontal Akibat Gempa

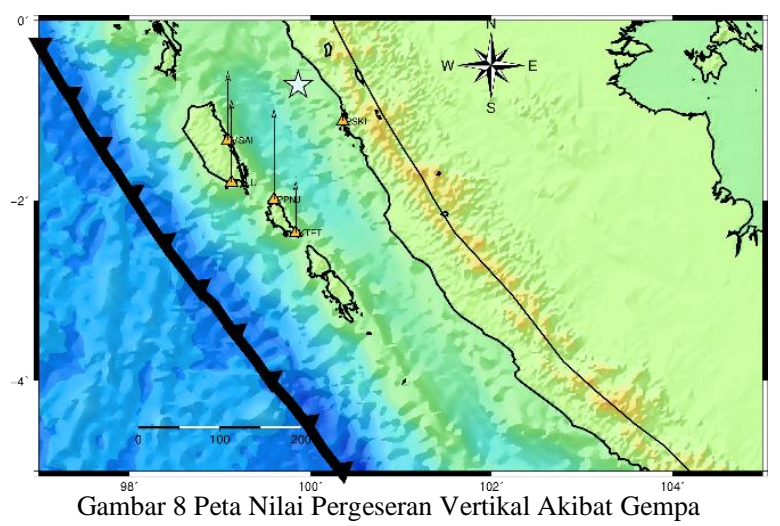

\section{KESIMPULAN/RINGKASAN}

Adapun beberapa hal yang dapat disimpulkan dari penelitian ini adalah Nilai pergeseran horizontal terbesar yang dihasilkan berdasarkan hasil pengolahan didapatkan dari stasiun pengamatan PPNJ yaitu sebesar $0.01222 \mathrm{~m}$ dan nilai pergeseran terkecil dihasilkan oleh stasiun pengamatan KTET yaitu sebesar $0.00185 \mathrm{~m}$.

Nilai pergeseran vertikal terbesar yang dihasilkan berdasarkan hasil pengolahan didapatkan dari stasiun pengamatan PPNJ yaitu sebesar $0.02083 \mathrm{~m}$ dan nilai pergeseran terkecil dihasilkan oleh stasiun pengamatan
PSKI yaitu sebesar $0.00277 \mathrm{~m}$.

Berdasarkan penelitian ini, data GPS SuGAr secara umum dapat digunakan untuk memantau fenomena geodinamika dalam hal ini adalah deformasi ataupun pergerakan lempeng yang terjadi akibat gempa bumi. Oleh karena itu, diperlukan penelitian yang lebih intensif dan waktu pengamatan yang lebih lama.

\section{UCAPAN TERIMA KASIH}

Penulis I.D.M.A.S mengucapkan terima kasih kepada Bapak Irwan Meilano karena telah membantu dalam pembuatan program model dislokasi elastic halfspace.

\section{DAFTAR PUSTAKA}

[1] H. Andreas, Karakteristik Deformasi Strain dan Stress, Bandung: Teknik Geodesi dan Geomatika ITB, 2007.

[2] R. Sule, S. F. Syamsuddin, D. S. Sarsito and I. A. Sadisun, The Utilization of Resistivity and GPS Methods in Landslide Monitoring: Case Study at Panagawan Area, Ciamis, Indonesi: Himpunan Alhi Geofisika Indonesa (HAGI), 2007.

[3] D. H. Natawidjaja, K. Sieh, R. Briggs, M. Chlieh, J. P. Avouac, J. Bock and B. W. Suwargadi, "Understanding the Nature of Giant Earthquake and Tsunamis in Sumatera-Andaman to Restore and Establish Safer Cities Around the Indian Ocean," in Memorial Conference on the 2004 Giant Earthquake.

[4] T. A. Herring, R. W. King and S. C. McClusky, Introduction to GAMIT/GLOBK, USA: Masschusetts Institute of Technology, 2010.

[5] A. S. Prasidya, Pengolahan Data GNSS Secara Loose Constraint dengan Modul GAMIT, Yogyakarta: Universitas Gadjah Mada, 2014.

[6] M. Yusfania, Pemodelan Mekanisme Gempa Bengkulu M8.5, Bandung: Institut Teknologi Bandung, 2008.

[7] I. N. Muafiry, Analisis Deformasi Akibat Gempa Bumi Kepulauan Mentawai Menggunakan Pengamatan GPS Kontinu, Surabaya: Institut Teknologi Sepuluh Nopember, 2015. 